\title{
Justyna Świrk
}

\section{Ekologiczna odpowiedzialność przedsiębiorstw w kontekście}

\author{
zapewnienia dobrego stanu \\ środowiska
}

Streszczenie: Ochrona środowiska stała się w ostatnich latach bardzo ważnym tematem nie tylko w polityce, ale także dla gospodarki światowej. Przedsiębiorstwa są organizacjami, które w istotny sposób wpływają na środowisko naturalne. Przedsiębiorcy mają tego świadomość czego efektem są powstające nowe koncepcje, które wpływają na zmianę myślenia o produkcji. Nie ma wątpliwości, że aspekt ekologiczny musi być brany pod uwagę w kontekście zarządzania firmą przyszłości. Zwrócenie uwagi przedsiębiorstwa na ekologiczny wymiar prowadzonej działalności znajduje swoje uzasadnienie nie tylko w etyce, ale również w ekonomii. Przegląd literatury wskazuje na wiele korzyści dla przedsiębiorstw płynących z wprowadzania odpowiednich praktyk w zakresie ochrony środowiska. Artykuł omawia pojęcie i istotę ekologicznej odpowiedzialności przedsiębiorstw przez pryzmat odpowiedzialności za przyszłe pokolenia. Celem artykułu jest analiza i ocena ekologicznej odpowiedzialności przedsiębiorstw z indeksu WIG-ESG, na podstawie informacji zawartych na oficjalnych stronach internetowych (działania środowiskowe realizowane przez przedsiębiorstwa, rodzaje praktyk prośrodowiskowych, analiza deklaracji odpowiedzialności za środowisko naturalne przez pryzmat dbałości o przyszłe pokolenia, próba odpowiedzi na pytanie - dlaczego przedsiębiorstwa z branż, które istotnie mogą wpływać na środowisko naturalne, są bardziej zainteresowane kwestiami środowiskowymi?). Wyniki badania pokazały, że firmy z indeksu WIG-ESG, w głównej mierze zainteresowane są działaniami związanymi z oszczędzaniem energii, gospodarką odpadami, zmniejszaniem emisji gazów cieplarnianych. Praktyki prośrodowiskowe związane są z procesami i produktami, a 40 proc. firm deklaruje odpowiedzialność za środowisko w kontekście odpowiedzialności za przyszłe pokolenia. Branże, które bardziej zanieczyszczają środowisko, mają wiele bodźców do ograniczania działań nieekologicznych.

Słowa kluczowe: odpowiedzialność przedsiębiorstw, przyszłe pokolenia, zrównoważony rozwój, ochrona środowiska 


\section{Corporate environmental responsibility in the context} of ensuring good environmental status

Summary: Environmental protection has become a very important topic in recent years, not only in politics but also in the world economy. Companies are individuals that have a very significant impact on the environment. Entrepreneurs are aware of this and new concepts are emerging that change and change thinking about production. There is no doubt that the ecological aspects must be taken into account in the management of the company of the future. Drawing the company's attention to the ecological dimension of its business is justified not only in ethics but also in economics. The literature review points to the many benefits for businesses of introducing responsible environmental practices. The article discusses the concept and essence of environmental responsibility for future generations. The aim of the article is to analyze and asses the environmental responsibility of enterprises from the WIG-ESG index on the basis of informations contained on official websites (environmental activities carried out by enterprises, types of pro-environmental practices, analysis of declarations of responsibility for the natural environment through the prism of care for future generations, an attempt to answer the question why industries that can significantly affect the natural environment are more interested in environmental issues? The results of the study showed that WIG-ESG companies are mainly interested to saving energy, waste management, reducing greenhouse gas emissions. Pro-environmental practices are related to processes and products and $40 \%$ of them declare responsibility for environment in terms of responsibility for future generations. Industries that pollute the environment more have many incentives to reduce non-ecological activities.

Keywords: responsibility of enterprises, future generations, sustainable development, environmental protection

JEL: JEL: Q56, M14, A13

Monetarystyczna szkoła myślenia postulowała, że głównym celem firmy jest maksymalizacja zysku i na organizacji ciąży odpowiedzialność za jego osiąganie. Odpowiedzialność w tym przypadku rozumiana jest jako odpowiedzialność wobec akcjonariuszy firmy, zatem należy maksymalizować zwrot z kapitału, nie bacząc na innych interesariuszy (Friedman, 1970, s. 6). Jednak samo osiąganie zysków to za mało, bowiem firmy w swojej działalności wykorzystują dobra naturalne, produkują zanieczyszczenia, zatem należy szerzej spojrzeć na przedsiębiorstwo i na jego odpowiedzialność za swoje działania.

Nowa ekonomia instytucjonalna rozpatrywała, jak powinno rozstrzygać się problem negatywnych efektów zewnętrznych: Czy powinno się pozwolić $A$, żeby szkodzit $B$, lub czy powinno się pozwolić B, żeby szkodzit $A$ ? (Coase, 2013, s. 87). Na przykład: jeżeli zatożymy, że szkodliwym skutkiem skażenia wody jest śnięcie ryb, kwestia do rozstrzygnięcia jest to, czy wartość strat $w$ rybach jest mniejsza czy większa niż wartość produktu, którego wytwarzanie wiąże się z zanieczyszczeniem strumienia (Coase, 2013, s. 87 za: Stigler, 1952, s. 105).

W kontekście środowiska trzeba jednak spojrzeć szerzej niż tylko na problem negatywnych efektów zewnętrznych i kosztu krańcowego, i szerzej niż na antropogeniczną 
teorię wartości \{traktowanie instrumentalnie wartości innych form życia, jako służące tylko ludziom (Callicott, 1984, s. 299)\}. W tych rozważaniach trzeba rozszerzyć grono interesariuszy o nowe podmioty - środowisko naturalne oraz przyszłe pokolenia, ponieważ to także na nie wpływa działalność przedsiębiorstwa, odnieść się do wartości moralnych i uznać globalność tych działań, bo wpływają na całą planetę. Takie podejście z kolei wymaga radykalnej transformacji biznesu, gdzie zrównoważenie biznesu, prospołeczność i zwiększenie wolności przyszłych pokoleń ma istotne znaczenie (Zsolnai, 2006, s. 37-38). Powodem takiego podejścia jest konstrukcja świata, który wzajemnie na siebie oddziałuje, a firmy są jego częścią.

\section{Ekologiczna odpowiedzialność przedsiębiorstw - definicja, istota, korzyści dla firm}

Ekologiczna odpowiedzialność przedsiębiorstw (ang. corporate environment responsibility - CER) lub environmental corporate social responsibility - ECSR) jest częścią składową społecznej odpowiedzialności przedsiębiorstw (ang. corporate social responsibility - CSR), czyli pozytywnych dziatań podejmowanych przez przedsiębiorcę, który ma na uwadze dobro szeroko pojmowanego spoteczeństwa (Bernatt, 2009, s. 29). Odpowiedzialność korporacji za środowisko to nowa forma współpracy między biznesem a środowiskiem (Ganescu, Dindire, 2014, s. 48), gdzie firmy biorą pod uwagę kwestie środowiskowe w swej działalności i relacjach z interesariuszami, nie pogarszając przy tym wyników ekonomicznych (Rashid et al., 2014, s. 499). Są trzy podejścia do relacji między gospodarką a środowiskiem (Borys, 2013, s. 14), w których określono pozycję przyszłych pokoleń:

- ekonomizacja środowiska przyrodniczego, które charakteryzuje myślenie w skali jednego pokolenia (Borys, 2013, s. 18),

- ekologizacja ekonomii i ekonomia ekologiczna, gdzie ważna jest jakość i dostępność zasobów środowiska dla przyszłych pokoleń (Borys, 2013, s. 20),

- ekonomia zrównoważonego rozwoju, gdzie zasadą samopodtrzymania rozwoju w wersji mocnej i restrykcyjnej jest sprawiedliwość międzypokoleniowa i wewnątrzpokoleniowa (Borys, 2013, s. 26).

Korporacyjna odpowiedzialność za środowisko jest związana z paradygmatem zrównoważonego rozwoju, który jest najbardziej pożądany z punktu widzenia gospodarki, ekologii i przyszłych pokoleń. Są trzy filary zrównoważonego rozwoju (Investopedia, 2019):

- środowiskowy - korzystny wpływ na planetę może mieć pozytywny wpływ na wynik finansowy,

- społeczny - zrównoważona firma powinna mieć wsparcie swoich pracowników, interesariuszy i społeczności w której działa,

- ekonomiczny - zysk ekonomiczny nie może „zaślepiać” pozostałych dwóch filarów.

Korporacyjna odpowiedzialność za środowisko zależy od wielu czynników, m.in. od branży, w której firma prowadzi swą działalność (największy wpływ na środowisko ma przemysł wytwórczy i produkcja żywności, w dalszej kolejności farmacja, handel, energia i paliwa (DNB Bank Polska i PwC, 2020). Również od tego, czy firma jest duża czy mała, w jakim kraju prowadzi swoją działalność, od religii np. istnieje negatywny związek między biblijnymi literalistami a odpowiedzialnością korporacyjną za środowisko (Spence, Brown, 2018, s. 46), a nawet od tego, czy firmą zarządza kobieta czy męż- 
czyzna (kobiety przedsiębiorcy są bardziej zaangażowane w kwestie środowiskowe niż mężczyźni) (Braun, 2010, s. 254). Firmy mogą mieć różne motywacje przyjęcia strategii środowiskowych, może to być np. presja interesariuszy, wyniki finansowe, wizerunek firmy (Cheema, Javed, 2017). Oprócz tego występują różnice pomiędzy korporacjami w zakresie zrównoważonego rozwoju. Wyróżnia się prawdziwe odpowiedzialne korporacje, sporadycznie niezrównoważone korporacje, okazjonalnie zrównoważone korporacje, konsekwentnie zrównoważone korporacje w wybranych obszarach i sporadycznie zrównoważone korporacje w wybranych obszarach (Ha-Brookshire, 2017, s. 231-232), które w różny sposób mogą traktować kwestie środowiskowe. Ważne jest także to, że nie wszyscy interesariusze cenią działania środowiskowe w równym stopniu (Heikkurinen, 2010, s. 144). Różne grupy interesariuszy są zainteresowane odmiennymi aspektami ochrony środowiska. Zdrowiem ludzkim i ekosystemem zainteresowani są ekolodzy, produkty, procesy i usługi przyjazne środowisku interesują związki zawodowe i organizacje ochrony konsumentów, a trwałym gospodarczym rozwojem najbardziej zainteresowane są rządy i organizacje międzynarodowe (Smaliukiene, 2007, s. 219).

Ekologiczna odpowiedzialność na poziomie firmy obejmuje praktyki związane z produktami - opracowanie bardziej ekologicznych produktów lub procesami - zmniejszenie ilości odpadów lub poprawa wykorzystania zasobów (Bowen, 2014, s. 40), a także z marketingiem, projektami edukacyjnymi, działalnością fundacji itp.

Ekologiczna odpowiedzialność przedsiębiorstw przynosi wiele korzyści:

- może poprawiać reputację firmy (Ganescu, Dindire, 2014, s. 50),

- obniża krótkoterminowe wyniki finansowe, ale może poprawić trwałość zysków i przynieść długoterminową wartość przedsiębiorstwu (Xu et al., 2020, s. 22-56)

- firmy przyjazne środowisku są postrzegane jako bardziej atrakcyjne dla poszukujących w nich pracy potencjalnych pracowników (Pfister, 2020, s. 101),

- konsumenci wolą produkty ekologiczne - przechodzenie od nadkonsumpcji do zielonej konsumpcji (Pimonenko et al., 2020); istnieje pozytywny związek między postrzeganym CER a lojalnością klientów, ważna jest komunikacja firm w tym zakresie, zwłaszcza z pokoleniem Y (Moisescu, Gica, 2020, s. 15),

- zwiększona konkurencyjność w porównaniu z firmami, które nie angażują się środowiskowo (Sim, Kim, 2019),

- koszt kapitału własnego jest niższy w firmach o wyższym CER (El Ghoul et al., 2018, s. 355),

- zapewnia lepszy dostęp do finansowania zewnętrznego, a w dłuższej perspektywie może skutecznie poprawić efektywność inwestycji (Zeng, 2019),

- w krajach rozwijających się, po zwiększeniu zaangażowania firmy w inicjatywy środowiskowe, jej wskaźnik ROA może wzrosnąć o 3,2 proc., a w krajach rozwiniętych o 1,1 proc. (DNB Bank Polska i PwC, 2020),

- ogranicza ryzyko firm, jeśli chodzi o koszty społeczne i odpowiedzialność za środowisko (Gangi et al., 2020, s. 987).

Oprócz korzyści istnieją także bariery w stosowaniu CER. Mają one charakter instytucjonalny, np. niedopasowane systemy nagród (realizacja celów osobistych) i/lub poznawczy (brak zaufania, własne indywidualne poglądy) (Sindhi, Kumar, 2012, s. 648).

Istnieją także bariery w pomiarze CER. Pojawiają się m.in. takie problemy, jak ograniczona dostępność danych (co jest mierzone), przejrzystość tego co jest ujawniane, jakość (dokładność i prawdziwość zgłaszanych danych). Branże różnie wpływają na śro- 
dowisko, zatem regulacje są odmienne, a standardowego systemu pomiarowego brakuje (Karassin, Bar-Haim, 2016, s. 114).

Wobec różnic i barier, jakie występują pomiędzy firmami w stosowaniu i pomiarze CER, każda firma musi odpowiedzieć sobie sama na pytanie, co może zrobić w kierunku ochrony środowiska, założyć realne cele, zastanowić się jakich zmian potrzebuje i jakie dobre praktyki wprowadzi.

\section{Odpowiedzialność za przyszłe pokolenia. Aspekt ekologiczny}

Koncepcja odpowiedzialności za przyszłe pokolenia to przedmiot filozoficznych rozważań i dyskusji od wielu lat (m.in. F.P. Ramsey, H. Jonas, J. Rawls). Pojawia się również od wielu lat w dyskursie politycznym, na co wskazuje liczba dokumentów wydanych $\mathrm{w}$ tej sprawie od początku lat 70. XX wieku, kiedy to rozpoczęta się filozoficzna debata o wytonieniu się nowej „ekologicznej” etyki, redefiniującej stosunek cztowieka do przyrody, aby zapewnić przetrwanie gatunkowi ludzkiemu na Ziemi (Gündling, 1990, s. 207). Do dokumentów tych należały m.in.: Manifest z Davos (1973), Raport Bruntlanda (1987), Zasady Okragtego Stotu z Caux (1994), Konwencja w sprawie ochrony światowego dziedzictwa kulturalnego i naturalnego - UNESCO, konferencja w Paryżu (1997), Agenda na rzecz zrównoważonego rozwoju 2030. Przeksztatcamy nasz świat, ONZ (2015). Ale poza rządem i rynkiem, firmy powinny być włączone do debaty nad ochroną interesów przyszłych pokoleń jako interesariuszy tych firm (Jeurissen, 2004, s. 47). A biznes ma przewage nad spoteczeństwem i aparatem państwa, jeżeli chodzi o skuteczność we wdrażaniu inicjatyw środowiskowych (DNB Bank Polska i PwC, 2020). Dlatego również przedsiębiorstwa muszą zmierzyć się z dylematami międzypokoleniowymi w aspekcie środowiska naturalnego.

Problem firm z odpowiedzialnością za przyszłe pokolenia jest taki, że przyszłość jest nieznana, trudna do wyobrażenia i nieprzewidywalna. Według Slaughter (1994, s. 1084), teraźniejsze pokolenie powinno postrzegać przyszłe pokolenia jako nierozerwalnie związane z ich własną teraźniejszością, własną rzeczywistością. Należy wprowadzić rozróżnienie między przyszłymi pokoleniami i następnymi pokoleniami i skupić się na następnych pokoleniach, a nie abstrakcyjnych przyszłych pokoleniach (Arenas, Rodrigo, 2016, s. 169). Obowiązków wobec przyszłych nie należy traktować w kategoriach metafizycznych, tylko w sposób racjonalny i rozsądny (Garcia-Portela, 2017, s. 99), odpowiednie podejście do przyszłych pokoleń może ułatwić wdrażanie rozwiązań, które uwzględnią je jako interesariuszy firm.

Istnieją dwa paradygmaty odpowiedzialności za przyszłe pokolenia (Birnbacher, 2009, s. 79):

- optymistyczny - zobowiązanie do przedłużenia procesu postępu i jego kontynuacja w przyszłości, przyszłe pokolenie jest lepsze niż obecne;

- pesymistyczny - unikanie szkód, przewidywanie przyszłych katastrof, minimalizacja ryzyka, przyszłe pokolenia są w gorszej sytuacji niż obecne pokolenia.

Jeżeli przyjąć ogólne założenie o międzypokoleniowej współzależności relacyjnej przyszłe pokolenia są zależne od obecnego pokolenia, a teraźniejszość zależy od możliwości przyszłych pokoleń (Randall, 2019, s. 536) - i że przyszłe pokolenia muszą wzrastać w warunkach co najmniej nie gorszych niż obecne pokolenie, to dziś istnieje ryzyko, że przyszłe pokolenia mogą nie mieć takiej szansy, nie tylko jeśli chodzi o środowisko, ale także o dobrobyt. I można przyjąć, że dziś świat funkcjonuje w pesymistycz- 
nym paradygmacie odpowiedzialności za przyszłe pokolenia, gdy trzeba zmierzyć się z zanieczyszczeniem powietrza, zmianami klimatycznymi, wyczerpywaniem zasobów naturalnych. Zgodnie z raportem OECD, całkowity roczny koszt rynkowy zanieczyszczenia powietrza zewnętrznego wzrośnie z 0,3 proc. w 2015 roku, do 1 proc. światowego PKB w 2060 roku (OECD, 2016). Tylko w Stanach Zjednoczonych, szkody gospodarcze związane ze zmianami klimatycznymi mogą osiągnąć równowartość 10 proc. PKB do końca stulecia (Jackson, 2020 za: NCA, 2018). Ponad 200 największych światowych firm oszacowało, że w przypadku niepodjęcia działań, zmiana klimatu kosztowałaby je łącznie prawie 1 bilion USD (Jackson, 2020 za: Green, 2019). Zanieczyszczenie powietrza zabija około $8 \mathrm{mln}$ ludzi rocznie, 25 proc. roślin i zwierząt w najbliższych dziesięcioleciach może wyginąć (prawie milion gatunków), ryby są poławiane na niezrównoważonych poziomach (33,1 proc.), od 1870 roku 50 proc. wszystkich raf koralowych zostało utracone, 20 proc. powierzchni lądów porośniętych roślinnością wykazywało spadek produktywności w latach 1998-2013 (United Nations, 2019, s. 95).

Szkody w środowisku są zagrożeniem dla trwałości wzrostu gospodarczego, mają one charakter potencjalnie strukturalny i nie wiadomo, czy już nie został osiągnięty punkt krytyczny (Reid et al., 2020) w kontekście ochrony przyszłych pokoleń firmy stoją przed dylematem - którymi poglądami się kierować? Czy poglądami enwironmentalistów - wyznawców katastroficznej wizji upadku i zagrożenia, gdzie człowiek niszczy glebę, wyczerpuje zapasy, powoduje zmiany klimatyczne, czy optymistyczną wizją wyznawców obfitości - technologia, wzrost gospodarczy i siły rynkowe są wybawcą (Samuelson, Nordhaus, 2012, s. 270-271). Dane są jednak niepokojące i należałoby zadać pytanie, czy sama technologia i „niewidzialna ręka rynku” zadbają o przyszłość?

\section{B Corp. Certyfikowana B Korporacja}

Myślenie o przyszłych pokoleniach jest perspektywiczne i długofalowe, co zauważa także biznes. Przykładem mogą być przedsiębiorstwa, które kierują się w swoich motywacjach odpowiedzialnego biznesu odpowiedzialnością za przyszłe pokolenia, np. w Kalifornii powstała koncepcja korporacji B (B Corp) i związana z nią koncepcja ekonomii B (B Economy). Korporacje B to certyfikowane firmy, które wykorzystują zyski i wzrost jako środek do osiągnięcia wyższego celu - pozytywnego wpływu na swoich pracowników, społeczność i środowisko, by nie wyrządzać szkody i przynieść wszystkim interesariuszom korzyści (B Lab, 2020), a zrównoważony rozwój mają wpisany w model biznesowy. Aktualnie certyfikat B Corp posiadają nie tylko duże międzynarodowe korporacje, ale także małe firmy.

\section{Badanie firm $\mathrm{z}$ indeksu WIG-ESG w zakresie deklaracji odpowiedzialności za środowisko w kontekście przyszłych pokoleń}

Firmy z indeksu WIG-ESG zbadano pod kątem informacji umieszczonych na ich oficjalnych stronach internetowych, dotyczących działań realizowanych w kontekście dbałości o środowisko naturalne, rodzajów praktyk prośrodowiskowych, deklaracji o trosce za przyszłe pokolenia w kontekście środowiskowym i motywacji firm do podjęcia działań proekologicznych. Do indeksu WIG-ESG należą największe spółki (60), które prowadzą działalność odpowiedzialną społecznie, w tym działalność odpowiedzialną środowiskowo. Indeks WIG-ESG, wprowadzony przez Giełdę Papierów Wartościowych w Warszawie 3 września 2019 roku, zastąpił RESPECT Index (zdjęty z giełdy 01.01.2020) i ma cel inwestycyjny (GPW, 2019). 
Firmy z indeksu WIG-ESG podejmują liczne działania związane z ochroną środowiska. $Z$ informacji zamieszczonych na oficjalnych stronach internetowych tych firm wynika, że obszarem, który je najbardziej interesuje w zakresie ochrony środowiska, to efektywność energetyczna/oszczęd ność energii, poczynając od biur (wyłączanie światła, komputera po godzinach pracy, „godzina bez prądu”, oświetlenie energooszczędne), po koncerny energetyczne, które wprowadzają zmiany w obrębie produktu jakim jest energia. Firmy w dużej mierze zwracają również uwagę na zarządzanie odpadami (recycling, segregacja, utylizacja), zmniejszanie emisji trujących gazów do atmosfery, zmniejszanie zużycia wody, edukację i angażowanie pracowników w kwestie środowiskowe, ograniczanie zużycia plastiku i papieru (np. e-faktury, korzystanie z papieru o obniżonej gramaturze, wyciągi bankowe tylko w formie elektronicznej, użycie papieru z recyclingu), wprowadzanie akcji związanych z ochroną bioróżnorodności (np. ochrona zagrożonych gatunków zwierząt) czy sadzeniem drzew. Do innych działań wskazywanych przez firmy należą: wprowadzanie hybrydowej floty samochodowej, zachęcanie pracowników do korzystania z rowerów (m.in. darmowe naprawy, stojaki), carpooling I carsharing, ograniczanie podróży służbowych do minimum, przeciwdziałanie marnowaniu żywności, niwelowanie hałasu, wybór odpowiedzialnych środowiskowo dostawców, zachęcanie klientów i lokalnych społeczności do zachowań ekologicznych. Firmy również zarządzają ryzykiem środowiskowym i monitorują działania wpływające na środowisko naturalne.

Rodzajem mechanizmów prośrodowiskowych, jakie większość firm wprowadziła, to dobre praktyki w obrębie procesów i produktów. Przy czym produkty bankowe są narzędziami ograniczającymi finansowanie firm, które w istotny sposób mogą wpływać na zanieczyszczenie środowiska i narzędziami wspierającymi kredytowanie inwestycji przyjaznych środowiskowo.

Branże, które bardziej zanieczyszczają środowisko (wydobycie, energetyka, budownictwo) podejmują więcej działań. Wynika to z jednej strony z istniejącego prawa (krajowego i unijnego), które wymaga pewnych działań (np. audytów energetycznych dla dużych firm), a z drugiej strony z zachowania banków, które nie chcą finansować „brudnych” biznesów, zachęcają poprzez kredyty do bardziej ekologicznych zachowań. Dlatego firmy te mają co najmniej podwójną motywację by ograniczać zanieczyszczanie środowiska. Ponadto, zwiększa się świadomość konsumentów (zwłaszcza młodszego pokolenia), pracowników, interesariuszy lokalnych, którzy są zainteresowani otoczeniem w którym żyją. Firmy zdają sobie sprawę z korzyści jakie niesie dbałość o środowisko (np. wprowadzają zieloną księgowość by monitorować koszty, zyski, móc ocenić i optymalizować działania środowiskowe), jak również dbają o swoją reputację. Firmy także zwracają uwagę w swoich działaniach na ochronę przyszłych pokoleń.

Badanie wykazało, że 24 z 60 firm, czyli 40 proc. firm indeksu WIG-ESG, ma zadeklarowaną odpowiedzialność za środowisko w kontekście przyszłych pokoleń. Najwięcej deklaracji o odpowiedzialności za środowisko w kontekście odpowiedzialności za przyszłe pokolenia składa energetyka (4/4 firmy), wydobycie i produkcja (3/3 firmy), odzież i obuwie (3/3 firmy) i górnictwo węgla/metali (3/3), czyli branże „brudne”, które istotnie mogą wpływać na zanieczyszczenie środowiska. Dodatkowo, dwie firmy ogólnie zwracają uwagę na dbałość o przyszłość pokoleń (po jednej firmie z branż bankowość korporacyjna i rekreacja/wypoczynek). Badanie ma swoje ograniczenia związane z tym, że firma może nie zadeklarować odpowiedzialności za przyszłe pokolenia, ale 
Tablica 1 Firmy (w podziale na branże) $\mathrm{z}$ indeksu WIG-ESG deklarujące odpowiedzialność za środowisko w kontekście ochrony przyszłych pokoleń

\begin{tabular}{|c|c|c|}
\hline branża & $\begin{array}{r}\text { liczba } \\
\text { firm } \\
\text { w branży }\end{array}$ & $\begin{array}{r}\text { liczba deklaracji } \\
\text { o odpowiedzialności za środowisko } \\
\text { w kontekście przyszłych pokoleń }\end{array}$ \\
\hline banki komercyjne & 10 & 2 \\
\hline budownictwo/deweloperzy/wynajem & 5 & 3 \\
\hline energetyka & 4 & 4 \\
\hline gry & 4 & 0 \\
\hline produkcja/dystrybucja leków & 4 & 1 \\
\hline wydobycie i produkcja & 3 & 3 \\
\hline górnictwo węgla/metali & 3 & 3 \\
\hline telekomunikacja & 3 & 1 \\
\hline odzież i obuwie & 3 & 3 \\
\hline systemy informatyczne & 2 & 0 \\
\hline artykuły codziennego użytku & 2 & 0 \\
\hline chemia podstawowa & 2 & 1 \\
\hline oprogramowanie & 2 & 0 \\
\hline hotele i restauracje/rekreacja i wypoczynek & 2 & 1 \\
\hline urządzenia mechaniczne & 1 & 1 \\
\hline hutnictwo metali nieżelaznych & 1 & 1 \\
\hline $\begin{array}{l}\text { inne (sprzęt elektryczny i elektroniczny, } \\
\text { giełdy i biura maklerskie, żywność, części } \\
\text { samochodowe, wierzytelności, ubezpieczenia, } \\
\text { transport, portale internetowe, } \\
\text { sprzęt i materiały medyczne) }\end{array}$ & 9 & 0 \\
\hline
\end{tabular}

Źródło: opracowanie własne na podstawie informacji z oficjalnych stron internetowych firm indeksu WIG-ESG na dzień 29.10.2020.

może mieć to w swojej filozofii. Ważne jest, by firmy podążały w kierunku paradygmatu zrównoważonego rozwoju, w którym troska o przyszłość ma istotne znaczenie. Z badania wynika, że istnieje pewna świadomość firm wpływu, jakim jest dbałość o środowisko na życie przyszłych pokoleń.

Warto w tym miejscu przytoczyć badanie Bortree et al. (2013), w którym analizowano, jak CER było ujmowane w reklamach dotyczących zrównoważonego rozwoju, zamieszczanych przez korporacje w magazynie National Geographic w latach 1979-2008. Badanie to wskazało, że w kwestii środowiskowej firmy koncentrują się na swoich zyskach, a nie na stratach (85 proc.), promocji siebie (78 proc.) i na problemach obecnego pokolenia (76 proc.), a nie przyszłych pokoleń (Bortree et al., 2013, s. 493). Od tego badania minęło kilka lat, obejmowało ono okres ogromnych zmian, jakie nastąpiły w myśleniu o środowisku i o przyszłych pokoleniach. Dzisiaj należy kierować się ku myśleniu o przyszłości. W kwestii środowiska firmy powinny podjąć działania zapobiegawcze a nie naprawcze (Heikkurinen, 2018, s.389). Potrzebne są dalsze badania w tym zakresie, zadające pytanie, czy dziś firmy rzeczywiście podążają tą ścieżką.

\section{Podsumowanie}

Firmy na świecie coraz bardziej zdają sobie sprawę w swoich działaniach z wagi brania pod uwagę nie tylko interesariuszy wewnętrznych, ale także zewnętrznych, takich jak środowisko czy przyszłe pokolenia. Myślenie o biznesie zmienia się również w Polsce. Badanie firm z indeksu WIG-ESG wskazuje, że 40 proc. firm indeksu deklaruje dbałość o środowisko w kontekście przyszłych pokoleń. Firmy podejmują liczne działania środowiskowe, z których najważniejszym jest efektywność energetyczna. Praktyki przyjazne środowisku dotyczą zarówno produktów jak i procesów. Przedsiębiorstwa 
mają motywację by zwracać uwagę na ekologię, np. poprzez podaż produktów finansowych promujących takie zachowania. Ważne jest, by motyw troski o przyszłe pokolenia stał się motywem przewodnim w myśleniu o środowisku naturalnym. Bowiem troska o środowisko i o przyszłe pokolenia jest w długiej perspektywie korzystna dla firm.

W toku rozważań literaturowych o odpowiedzialności firm za środowisko, i w związku z tym za przyszłe pokolenia, można stwierdzić, że jedynym celem firmy nie może być maksymalizacja zysku. Bowiem, tak jak mówi pewne przysłowie indiańskie - „kiedy wycięte zostanie ostatnie drzewo, ostatnia rzeka zostanie zatruta i zginie ostatnia ryba - odkryjemy, że nie można jeść pieniędzy”. Dlatego w dyskursie naukowym i biznesowym powinno się szczególnie skoncentrować na roli troski za przyszłe pokolenia jako cel firmy i tę odpowiedzialność wbudować w strategię firmy, bowiem troska o przyszłość, o środowisko i maksymalizacja zysków firmy to nie jest gra o sumie zerowej.

\section{Bibliografia:}

1. Arenas D., Rodrigo P. (2016), On Firms and the Next Generations: Difficulties and Possibilities for Business Ethics Inquiry, "Journal of Business Ethics", Vol. 13(1), p. 165-178.

2. B Lab (2020), Certified B Corporation, https://bcorporation.net/about-b-corps, dostęp 17.10.2020.

3. Bernatt M. (2009), Spoteczna odpowiedzialność biznesu. Wymiar konstytucyjny i międzynarodowy, Warszawa, WN Wydziału Zarządzania Uniwersytetu Warszawskiego.

4. Birnbacher D. (2009), Responsibility for Future Generations - Scope and Limits, "Studia Ecologicae et Bioethicae", Vol. 7(1), p. 75-106.

5. Bortree D.S., Ahern L., Smith A.N., Dou X. (2013), Framing environmental responsibility: 30 years of CSR messages in National Geographic Magazine, "Public Relations Review", Vol. 39(5), p. 491-496.

6. Borys T. (2013), Nowe kierunki ekonomii srodowiska i zasobów naturalnych w aspekcie nowej perspektywy finansowej Unii Europejskiej, „Ekonomia i Środowisko”, Vol. 1(44), s. 8-28.

7. Bowen F. (2014), After Greenwashing. Symbolic Environmentalism and Society, Cambridge, Cambridge University Press.

8. Braun P. (2010), Going green: women entrepreneurs and the environment, "International Journal of Gender and Entrepreneurship", Vol. 2(3), p. 245-259.

9. Callicott J.B. (1984), Non-antropocentric value theory and environmental ethics, "American Philosophical Quarterly", Vol. 21(4), p. 299-309.

10. Cheema S., Javed F. (2017), The effects of corporate social responsibility toward green human resource management: The mediating role of sustainable development, "Cogent Business \& Management", Vol. 4( 1).

11. Coase R.H. (2013), Firma, rynek i prawo, Warszawa, Oficyna a Wolters Kluwer business.

12. El Ghoul S., Guedhami O., Kim H., Park K. (2018), Corporate environmental responsibility and the cost of capital: International evidence, "Journal of Business Ethics", Vol. 149 (2), p. 335-361.

13. DNB Bank Polska S.A. i PwC (2020), Kierunki 2020. Zielona odpowiedzialność biznesu. Czy biznes przyjazny środowisku się optaca?, https://www.dnb.pl/pl/o-banku , dostęp 17.10.2020.

14. Friedman M. (1970), The Social Responsibility of Business is to Increase its Profits, "The New York Times Magazine”, p. 1-6, http://umich.edu/thecore/doc/Friedman.pdf, dostęp 18.10.2020.

15. Ganescu C., Dindire L. (2014), Corporate environmental responsibility - a key determinant of corporate reputation, "Computational Methods in Social Sciences", Vol. 2(1), p. 48-53.

16. Gangi F., Daniele L.M., Varrone N. (2020), How do corporate environmental policy and corporate reputation affect risk-adjusted financial performance?, "Business Strategy and the Environment", Vol. 29(5), p. 1975-1991. 
17. Garcia-Portela L. (2017), Our responsibility to future generations in the context of ecological crisis, “American Journal of Semiotics", Vol. 33(1-2), p. 99-112.

18. GPW (2019), GPW uruchamia indeks WIG-ESG, www.gp.pl, dostęp 22.10.2020.

19. Green M. (2019), Reuters, World's Biggest Firms Foresee \$1 Trilion Climate Cost Hit, https://www.reuters.com.

20. Gündling L. (1990), Our responsibility to future generations, "American Journal of International Law”, Vol. 84(1), p. 207-212.

21. Ha-Brookshire J. (2017), Toward Moral Responsibility Theories of Corporate Sustainability and Sustainable Supply Chain, "Journal of Business Ethics”, Tom 145, Nr 2, p. 227-237.

22. Heikkurinen P. (2010), Image Differentiation with Corporate Environmental Responsibility, "Corporate Social Responsibility and Environmental Management", Vol. 17( 3), p. 142-152.

23. Heikkurinen P. (2018), Strategic corporate responsibility: a theory review and synthesis, "Journal of Global Responsibility”, Vol. 9( 4), p. 388-414.

24. Investopedia (2019), The 3 Pillars of Corporate Sustainability, https://www.investopedia.com, dostęp 17.10.2020.

25. Jackson L. (2020), World Economic Forum, A Decade Left. Confronting Runaway Climate Threat, https://reports.weforum.org, dostęp 17.10.2020.

26. Jeurissen R., Keijzers G. (2004), Future generations and business ethics, "Business Ethics Quarterly", Vol. 14(1), p. 47-69.

27. Karassin O., Bar-Haim A. (2016), Multilevel corporate environmental responsibility, "Journal of Environmental Management", Vol. 183, part 1, p. 110-120.

28. Moisescu O.I., Gica O.A. (2020), The Impact of Environmental and Social Responsibility on Customer Loyalty: A Multigroup Analysis among Generations $X$ and $Y$, "International Journal of Environmental Research and Public Health", Tom 17, Nr 18, p. 1-22.

29. NCA (2018), Fourth National climate Assessment Volume II: Impacts, Risk and adaptation in the United States, National Climate Assessment, https://nca2018.globalchange.gov.

30. OECD (2016), The economic consequences of outdoor air pollution. Policy Highlights, https://www.oecd.org, dostęp 18.10.2020.

31. Pfister M. (2020), Corporte Social Responsibility and Organizational Attraction: A Systematic Literature Review, “American Journal of Management”, Vol. 20(2), p. 96-111.

32. Pimonenko T., Bilan Y., Horak J., Starchenko L., Gajda W. (2020), Green Brand of Companies and Greenwashing under Sustainable Development Goals, „Sustainability”, Vol. 12(4).

33. Randall T. (2019), Care Ethics and Obligations to Future Generations, "Hypatia. A Journal of Feminist Philosophy", Vol. 34(3), p. 527-545.

34. Rashid N.R.N.A, Rahman N.I.A., Khalid S.A. (2014), Environmental Corporate Social Responsibility (ECSR) as a Strategic Marketing Initiatives, "Procedia - Social and Behavioral Sciences", Vol. 130, p. 499-508.

35. Reid J., Templeman L., Allen H. (2020), Davos 2020: We need to talk about (sustainable) growth, Deutsche Bank Research, https://www.dbresearch.com, dostęp 18.10.2020.

36. Samuelson P.A., Nordhaus W.D. (2012), Ekonomia, Poznań, Dom Wydawniczy REBIS Sp. z o.o..

37. Sim J.E., Kim B. (2019), Commitment to Environmental and Climate Change Sustainability under Competition, "Sustainability”, Vol. 11(7).

38. Sindhi S., Kumar N. (2012), Corporate environmental responsibility - transitional and evolving, "Management of Environmental Quality”, Tom 23(6), p. 640-657.

39. Slaughter R.A. (1994), Why we should care for future generations now, "Futures", Vol. 26(10), p. $1077-1085$.

40. Smaliukiene R. (2007), Stakeholders' impact on the environmental responsibility: Model design and testing, "Journal of Business Economics and Management", Vol. 8(3), p. 213-223. 
41. Spence M.B., Brown L.W. (2018), Theology and Corporate Environmental Responsibility: A Biblical Literalism Approach to Creation Care, "Journal of Biblical Integration in Business", Vol. 21(1), p. 45-54. 42. Stigler G.J. (1952), The Theory of Price, New York, wyd. popr., Macmillan Co.

43. United Nations (2019), The Future is now - Science for Achieving Sustainable Development, Global Sustainable Development Report 2019, https://sustainabledevelopment.un.org, dostęp 17.10.2020.

44. Xu F., Yang M., Li Q., Yang X. (2020), Long-term economic consequences of corporate environmental responsibility: Evidence from heavily polluting listed companies in China, "Business Strategy and Environment", Vol. 29(6), p. 2251-2264.

45. Zeng S., Qin Y., Zeng G. (2019), Impact of Corporate Environmental Responsibility on Investment Efficiency: The Moderating Roles of the Institutional Environment and Consumer Environmental Awareness, "Sustainability”, Vol. 11(17).

46. Zsolnai L. (2006), Extended stakeholder theory, "Society and Business Review”, Tom 1, No 1, p. $37-44$.

Mgr Justyna Świrk, doktorantka Kolegium Zarządzania i Finansów, Szkoła Główna Handlowaw Warszawie, js65573@doktorant.sgh.waw.pl 